\title{
26. BACTERIAL PROFILES IN DEEP SEDIMENT LAYERS FROM THE EASTERN EQUATORIAL PACIFIC OCEAN, SITE $851^{1}$
}

\author{
B.A. $\mathrm{Cragg}^{2}$ and A.E.S. Kemp ${ }^{3}$
}

\begin{abstract}
Bacterial depth profiles were obtained from sediment samples taken from a deep-water $(3761 \mathrm{~m})$ site in the eastern equatorial Pacific to a depth of $317.4 \mathrm{~m}$ below seafloor (mbsf) using the Acridine Orange direct count (AODC) technique. Bacterial cells were observed at all depths and dividing/divided cells were observed in 47 of 58 samples. Numbers were consistent with a low organic carbon environment. Total counts decreased from near-surface levels of $2.08 \times 10^{8}$ to $4.88 \times 10^{5} \mathrm{cells} / \mathrm{cm}^{3}$ at $12 \mathrm{mbsf}$ before increasing to a local maximum of $9.33 \times 10^{6} \mathrm{cells} / \mathrm{cm}^{3}$ at $91 \mathrm{mbsf}$. The maximum number of dividing/divided cells $\left(4.85 \times 10^{7} \mathrm{cells} / \mathrm{cm}^{3}\right)$ were detected at the near-surface. They decreased to "not detectable" by $4.5 \mathrm{mbsf}$ and did not display a sustained increase in numbers until approximately $30 \mathrm{mbsf}$, with a peak at $2.62 \times 10^{6} \mathrm{cells} / \mathrm{cm}^{3}$ at $91 \mathrm{mbsf}$. The increase in counts below $30 \mathrm{mbsf}$ was attributed to a change in the depositional history resulting in elevated buried organic carbon concentrations between 30 and $290 \mathrm{mbsf}$. Dividing/divided cell counts may provide an index of the bioavailability of this organic carbon. Inorganic and organic chemical profiles correlated significantly with bacterial counts and indicated a zone of limited bacterial activity (sulfate reduction and methanogenesis) between 30 and 290 mbsf. The reasons for the existence of a band of low total counts and almost negligible dividing/divided cell counts between 1.5 and $25-30 \mathrm{mbsf}$ is not understood, as the chemical profiles suggest that bacteria should be both present and active.

When compared with equivalent bacterial counts taken on sediment samples from the Peru Margin and Japan Sea (areas of higher oceanic productivity) and Lau Basin (lower oceanic productivity), near-surface total counts were lower than those in the Lau Basin. This is attributed to considerably lower concentrations of organic carbon $(0.06 \%$ compared with $0.27 \%)$ in the near-surface sediments at this site owing to greater water depth. The rate decrease in both the total and dividing/divided cell counts over the top 80 mbsf was less than that observed in the Lau Basin (but greater than in the Peru Margin or Japan Sea); however, this observation is probably related to the depositional history of the site, rather than the overlying oceanic productivity.
\end{abstract}

\section{INTRODUCTION}

Sediment bacteria play a central role in the biogeochemical cycling of the elements (Jørgensen, 1983) and are intimately involved in both remineralization and selective preservation of organic matter in marine sediments. The importance of their presence and activity at the sediment surface has long been accepted (Sørensen, 1978; Sørensen and Jørgensen, 1987). Here, they are at the interface between the water column and the sediment, where sinking detrital microaggregates concentrate in an oxic or dysoxic environment to produce a favorable habitat for bacterial growth (Lochte and Turley, 1988; Turley and Lochte, 1990). It is only relatively recently, however, that their importance in much deeper sediments has become more widely accepted, with more thorough investigations of indirect evidence suggesting that bacteria are active to significant depths (e.g., chemical changes in pore water, production of kerogen, concretion formation, and isotopic evidence; Krumbein, 1983).

Early evidence of the existence of deep sediment bacterial populations (Rittenberg, 1940; ZoBell, 1958; Davis, 1967) was restricted by the techniques available to obtain and culture sediment samples, which resulted in an elevated potential for contamination of deep sediment layers by the more active surface sediments. Using more rigorous methods, recent workers have reported the detection and cultivation of bacteria to $200 \mathrm{~m}$ below seafloor (mbsf) (Oremland et al., 1982; Belyaev and Ivanov, 1983; Bianchi, 1986) and their presence has been demonstrated to more than 400 mbsf in aquifers (White

${ }^{1}$ Pisias, N.G., Mayer, L.A., Janecek, T.R., Palmer-Julson, A., and van Andel, T.H. (Eds.), 1995. Proc. ODP, Sci. Results, 138: College Station, TX (Ocean Drilling Program), ${ }^{2}$ Department of Geology, University of Bristol, Bristol BS8 1RJ, United Kingdom.

${ }^{3}$ Department of Oceanography, The University, Southampton SO9 5NH, United Kingdom. et al., 1983; Balkwill, 1989; Erlich and Ghiorse, 1989; Phelps et al., 1989; Chapelle and Lovley, 1990; Fredrickson et al., 1991).

In marine environments, positive evidence for low levels of anaerobic bacterial activity (methanogenesis and sulfate reduction) has been found in sediments to $167 \mathrm{mbsf}$ in the Gulf of Mexico and the North Atlantic (Whelan et al., 1986; Tarafa et al., 1987). Cragg et al. (1990) and Parkes et al. (1990) described bacterial populations associated with significant levels of sulfate reduction and methanogenic activity in a comprehensive study of sediments from the Peru Margin to $80 \mathrm{mbsf}$. More recently, significant bacterial populations linked to low levels of activity have been reported to more than $500 \mathrm{mbsf}$ in sediment samples from the Japan Sea (Cragg et al., 1992; Getliff et al., 1992).

Both the Peru Margin and the Japan Sea are relatively shallow sites (150 and 900 mbsf, respectively) in areas of comparatively high oceanic productivity. Interestingly, results obtained to more than $100 \mathrm{mbsf}$ from the Lau Basin, a deep (2692 mbsf) mid-Pacific site in an area of low oceanic productivity, also revealed bacteria present at all depths sampled, albeit at greatly reduced levels, with counts decreasing at a significantly faster rate with depth when compared to more productive sites (Cragg, in press). Geochemical data provided no indirect evidence for any bacterial activity and the low levels of buried organic carbon reported in the data suggested that the bacterial populations were merely surviving in an extreme low-energy environment.

Ocean Drilling Program (ODP) Site 851 in the eastern equatorial Pacific is a deep-water area $(3761 \mathrm{~m})$ with an annual water column primary productivity rate between that of the Lau Basin and the Japan Sea (Berger, 1989). The bulk of the material deposited as sediments onto the seafloor over the last $11 \mathrm{~m} . \mathrm{y}$. has consisted of biogenic carbonates in the form of coccoliths and foraminifers and biogenic opal mainly as diatoms with subordinate radiolarians (Mayer, Pisias, Janecek, et al., 1992). Sediment core samples were obtained from this site on Leg 138 to determine the presence, concentration, and depth distribution of sediment bacteria in such an environment. 


\section{MATERIALS AND METHODS}

\section{Shipboard Handling}

Sediment samples were removed from 58 core sections, between 0 and $317.4 \mathrm{mbsf}$, of Holes 851A and 851B (Table 1). Hole 851 A was a single mud-line core taken to capture the surficial sediments. Nevertheless, a significant amount of loose sediment will have been displaced during penetration of the corer, and so the sample from $0 \mathrm{mbsf}$ is more properly defined as near-surface. Pollen analysis evidence from similar mud-line cores taken in the Japan Sea suggested that some $60 \mathrm{~cm}$ had been lost from the top of the first core (L. Heusser, pers. comm., 1991). Immediately after a core was cut into 1.5 -m sections on the outside catwalk, a thin layer of sediment was removed from the section end using a sterile scalpel to expose an uncontaminated surface. A $2-\mathrm{cm}^{3}$ sample was then taken with a sterile (autoclaved) $5-\mathrm{mL}$ syringe from which the leur end had been removed. The sample was divided in two with $1 \mathrm{~cm}^{3}$ ejected directly into a tared serum vial containing $9 \mathrm{~mL}$ of filter-sterilized $(0.2 \mu \mathrm{m}) 4 \%$ formaldehyde in artificial seawater and the second $1 \mathrm{~cm}^{3}$ placed in a glass sample vial for wet/dry-weight determination.

\section{Laboratory Handling}

\section{Direct Microscopic Observations}

Acridine Orange staining and microscopic observations were based on the general recommendations of Fry (1988) with minor modification. Fixed samples were vortex mixed and between 15 and $40 \mu \mathrm{L}$ added to $10 \mathrm{~mL}$ of $2 \%$ filter-sterilized $(0.1 \mu \mathrm{m})$ formaldehyde in $2.5 \%$ acetic acid $(\mathrm{vol} / \mathrm{vol})$. Acridine Orange $(50 \mu \mathrm{L})$ was added to give a final concentration of $5 \mathrm{mg} / \mathrm{dm}^{3}$. After $3 \mathrm{~min}$, the solution was filtered through a $25-\mathrm{mm}$ Nucleopore black polycarbonate membrane (Appleton Woods, Birmingham, U.K.) of $0.2-\mu \mathrm{m}$ pore size. The filter was rinsed with a further $10 \mathrm{~mL}$ of $2 \%$ filter-sterilized formaldehyde in $2.5 \%$ acetic acid and mounted in a minimum amount of paraffin oil under a cover slip. The sediment samples had a particularly high carbonate concentration (approximately $75 \%$ with some intervals of $20 \%-50 \%$; Mayer, Pisias, Janecek, et al., 1992), and the large number of carbonate particles concealed bacterial cells when viewed through a microscope, which necessitated an undesirable dilution of the sample to obtain a reliable count. The use of acetic acid removed this problem by dissolving the carbonate. A check of this technique on two marine sediments from different areas of the world, counting in triplicate both with and without acetic acid, showed no significant difference in either total cell count or dividing cell count between treatments $(F=0.366 ;$ d.f. $=1,8 ; P=0.56$, and $F=0.204$; d.f. $=1,8 ; P=0.67$, respectively).

Mounted membrane filters were viewed under incident illumination with a Zeiss Axioskop microscope fitted with a 50-W mercuryvapor lamp, a wide-band interference set for blue excitation, a 100x (numerical aperture $=1.3$ ) Plan Neofluar objective lens, and $10 \times$ eyepieces. Bacterially shaped green and red fluorescing objects were counted. Cells on or off particles were counted separately, and the numbers of those on particles were doubled in the final calculations to account for cells hidden from view by particles (Goulder, 1977). Dividing cells (those with a clear invagination) and divided cells (pairs of cells of identical morphology) also were counted.

\section{Porosity and Organic Matter}

Sediment wet/dry-weight ratios and porosity were obtained by drying the tared $1 \mathrm{~cm}^{3}$ of sediment to constant weight at $105^{\circ} \mathrm{C}$. Organic matter content was estimated by heating subsamples of dried sediment in a muffle furnace at $450^{\circ} \mathrm{C}$ to constant weight. After the sample had been destructively treated for this measurement, a small random error was detected in the balance, making the data unreliable, and they were discarded. Shipboard data have been used where necessary.
Table 1. List of Leg 138 Holes 851A and 851B samples provided for direct bacterial counts.

\begin{tabular}{ccccc}
\hline Hole & Position & Water depth $(\mathrm{m})$ & $\begin{array}{c}\text { Maximum sample } \\
\text { depth (mbsf) }\end{array}$ & $\begin{array}{c}\text { Number of } \\
\text { samples }\end{array}$ \\
\hline $851 \mathrm{~A}$ & $\begin{array}{r}2^{\circ} 46.218^{\prime} \mathrm{N} \\
110^{\circ} 34.308^{\prime} \mathrm{W}\end{array}$ & 3779.5 & 4.51 & 3 \\
$851 \mathrm{~B}$ & $\begin{array}{r}2^{\circ} 46.218^{\prime} \mathrm{N} \\
110^{\circ} 34.308^{\prime} \mathrm{W}\end{array}$ & 3760.3 & 317.4 & 55 \\
\hline
\end{tabular}

\section{RESULTS AND DISCUSSION}

A paired sample t-test performed on bacterial count data from congruent depths of the mud-line core of Hole 851A and the first core of Hole $851 \mathrm{~B}$ showed no significant difference $(P>0.05)$ between the two cores, and the data were combined.

A significance limit was constructed from the data by selecting all counts where fewer than 20 cells in total were enumerated on a membrane and calculating the total count on the basis of a single cell encountered on that membrane. The mean and $95 \%$ confidence limits of these results was $1.49 \times 10^{5} \pm 1.07 \times 10^{4} \mathrm{cells} / \mathrm{cm}^{3}$. The significance limit was set to the mean plus $95 \%$ confidence limit at $1.60 \times 10^{5}$ cells $/ \mathrm{cm}^{3}$ or $5.20 \log _{10}$ units (Fig. 1).

Bacteria were present in all samples to $317.4 \mathrm{mbsf}$ (Fig. 1). The abrupt decline in numbers between the near-surface $\left(2.08 \times 10^{8}\right.$ cells $/$ $\left.\mathrm{cm}^{3}\right)$ and $12 \mathrm{mbsf}\left(4.88 \times 10^{5}\right.$ cells $\left./ \mathrm{cm}^{3}\right)$ represents a 427 -fold decrease. This was a local minimum after which counts sharply increased to $2.98 \times 10^{6}$ cells $/ \mathrm{cm}^{3}$ by $21.5 \mathrm{mbsf}$, a six-fold increase on the minimum, and then more gradually increased to $9.33 \times 10^{6}$ cells $/ \mathrm{cm}^{3}$ at 91 mbsf, a 19-fold increase, on the minimum. This latter count was the highest obtained below the first near-surface value and was in a local group of relatively high counts between 75.5 and 97.5 mbsf (average $\left.=5.76 \times 10^{6} \mathrm{cells} / \mathrm{cm}^{3}\right)$. Thereafter, the numbers of bacteria gradually declined to $1.38 \times 10^{6} \mathrm{cells} / \mathrm{cm}^{3}$ at $307.7 \mathrm{mbsf}$. There was a sharp decrease (approximately 3.7 -fold) in cell numbers between this depth and the deepest sample at $317.4 \mathrm{mbsf}$ to $3.73 \times 10^{5} \mathrm{cells} / \mathrm{cm}^{3}$, which was the lowest count obtained and represented a 558-fold decrease on the near-surface count. This last sample was taken $6 \mathrm{~m}$ above basement (Mayer, Pisias, Janecek, et al., 1992).

Site 851 presently occupies a position near the northern margin of the equatorial high-productivity zone. The average annual primary productivity of the overlying water at this site is therefore relatively high (Berger, 1989), and despite a greater depth than at other ODP sites for which similar bacterial counts have been made (Cragg, in press), these data can be placed between a slightly more productive Japan Sea and a substantially less productive Lau Basin (Table 2). Nevertheless, the greater water depth does reduce the proportion and quality of primary production reaching the seafloor (Jørgensen, 1983). This is revealed in the depth-weighted mean organic carbon content, calculated over the upper $105 \mathrm{~m}$ at both sites, of approximately $0.17 \%$ for sediments from the Lau Basin Site 834 (derived from Parson, Hawkins, Allan, et al., 1992), compared with approximately $0.10 \%$ in the sediments from Site 851 (derived from Mayer, Pisias, Janecek, et al., 1992); a difference that is accentuated when calculations are performed on data from Pleistocene sediments only, with $0.27 \%$ organic carbon at Site 834 (0-32 mbsf) compared with $0.06 \%$ at Site 851 (0-26 mbsf). This is reflected in lower bacterial counts at both the near-surface and at approximately 80 mbsf compared with the Lau Basin site (Table 2). It is, therefore, perhaps more meaningful to sequence these data according to the overlying water depth from Legs 112 through 138 .

Because at approximately 80 mbsf a comparatively high percentage of the near-surface count remains at Site 851 (2.0\%), placing the data firmly between Legs 128 and 135, Table 2 is slightly misleading. At $80 \mathrm{mbsf}$ the total count is still increasing from a minimum of $4.88 \times 10^{5}$ cells $/ \mathrm{cm}^{3}$ at $12 \mathrm{mbsf}$ to a maximum of $9.33 \times 10^{6} \mathrm{cells} / \mathrm{cm}^{3}$ at $91 \mathrm{mbsf}$. A possible explanation for this inconsistency is provided by evidence of significant variations in the amount of buried deposi- 
Table 2. Comparison of direct bacterial count data from ODP legs for total counts and dividing cell counts.

\begin{tabular}{|c|c|c|c|c|}
\hline \multirow{2}{*}{ Leg: } & \multicolumn{4}{|c|}{ Cells $/ \mathrm{cm}^{3}$} \\
\hline & 112 & 128 & 138 & 135 \\
\hline & Peru & Japan & Equatorial & Lau \\
\hline & Margin & Sea & Pacific & Basin \\
\hline Hole: & $681 \mathrm{C}$ & $798 \mathrm{~B}$ & $851 \mathrm{~A} / \mathrm{B}$ & $834 \mathrm{~A}$ \\
\hline Water depth $(\mathrm{m})$ : & 150 & 900 & 3761 & 2692 \\
\hline \multicolumn{5}{|l|}{ Total coumts } \\
\hline & (1.5 mbsf & $(0 \mathrm{mbsf})_{8}$ & $(0 \mathrm{mbsf})_{\mathrm{g}}$ & $(0 \mathrm{mbsf})_{8}$ \\
\hline Near-surface & $1.06 \times 10^{9}$ & $7.82 \times 10^{8}$ & $2.08 \times 10^{8}$ & $6.12 \times 10^{8}$ \\
\hline Approximately & (80.2 mbsf) & (78.9 mbsf) & (78.5 mbsf) & (81.6 mbsf) \\
\hline $80 \mathrm{mbsf}$ & $3.33 \times 10^{8}$ & $1.71 \times 10^{7}$ & $4.24 \times 10^{6}$ & $7.50 \times 10^{6}$ \\
\hline Percentage near-surface & 31 & 2.2 & 2.0 & 1.2 \\
\hline \multicolumn{5}{|l|}{ Dividing cell counts } \\
\hline & $\left(1.5 \mathrm{mbsf}_{3}\right.$ & $(0 \mathrm{mbsf})$ & $(0 \mathrm{mbsf})_{7}$ & $(0 \mathrm{mbsf})_{7}$ \\
\hline Approximately & $(80.2 \mathrm{mbsf})$ & $(78.9 \mathrm{mbs}$ ) & $(78.5 \mathrm{mbs})$ & 8.76 mbso \\
\hline $80 \mathrm{mbsf}$ & $1.94 \times 10^{6}$ & $1.14010^{\circ}$ & $6.60 \times 10^{3}$ & $4.05010^{5}$ \\
\hline Percentage near-surface & 2.2 & 1.8 & 1.4 & 0.4 \\
\hline
\end{tabular}

Notes: Oceanic productivity relationship from Berger (1989). Depth data from Suess, von Huene, et al. (1988; Leg 112); Ingle, Suyehiro, von Breymann, et al. (1990; Leg 128): Parson. Hawkins, Allan, et al. (1992; Leg 135); and Mayer. Pisais, Janecek, et al. (1992; Leg 138), with 0 mbsf, defined according to ODP. Approximately $80 \mathrm{mbsf}$ selected as the comparison depth, as this was the deepest sample counted at Leg 112 Hole 681 C (Cragg et al., 1990; adapted from Cragg, in press). Bacterial data from Cragg et al. (1990; Leg 112), Cragg et al. (1992; Leg 128) and Cragg (in press; Leg 135).

tional organic carbon, which is linked to large changes in sedimentation rates over time (Fig. 2). The current deposition rate, estimated over the top $11.2 \mathrm{~m}$ of the sediment to be $16.6 \mathrm{~m} / \mathrm{m}$.y., is particularly low and is associated with a relatively low buried organic carbon concentration of approximately $0.06 \%$. Additionally, conditions are believed to be only weakly reducing in the top $5 \mathrm{~m}$ relative to the nearer-equator Sites 849 and 850 (Mayer, Pisias, Janecek, et al., 1992). In such an environment the bacterial populations are most likely to be dominated by aerobic, microaerophilic, and facultatively anaerobic heterotrophs, which will rapidly metabolize any labile organic carbon leaving only the more recalcitrant carbon to be subsequently buried. This would be demonstrated by a comparatively large surficial bacterial population that abruptly declines in numbers as depth increases (Fig. 1). Clearly, this depositional environment has not always existed. For example, between 29.3 and $103.3 \mathrm{mbsf}$ the deposition rate increased from 10.3 to $59.6 \mathrm{~m} / \mathrm{m}$.y. concurrent with an increase in buried organic carbon from $0.08 \%$ to $0.18 \%$ over an approximately $3.3-\mathrm{m} . y$. time period (Fig. 2). This increase in organic carbon is coincident with the increase in bacterial counts over the same depth range (Fig. 1).

Significant numbers of dividing cells were present in 47 of the 58 samples (Fig. 1). The highest value was at the near-surface at $4.85 \times 10^{7}$ cells $/ \mathrm{cm}^{3}$ after which the count abruptly declined to "not-detectable" by $4.5 \mathrm{mbsf}$, where it was constant until $15 \mathrm{mbsf}$. The dividing cell count then increased to $7.41 \times 10^{5}$ cells $/ \mathrm{cm}^{3}$ at $21.5 \mathrm{mbsf}(1.5 \%$ of the near-surface count) before decreasing to not-detectable again by $28 \mathrm{mbsf}$. From $34 \mathrm{mbsf}$ the count gradually increased to a local maximum of $2.62 \times 10^{6}$ cells $/ \mathrm{cm}^{3}$ at $91 \mathrm{mbsf}$, which represents approximately $5 \%$ of the near surface count. Thereafter, cell numbers declined gradually with depth, with recorded nondetectables at 243.6 and $317.4 \mathrm{mbsf}$.

The dividing cell profile correlates well with that of the total count ( $R=0.908, N=45, P<0.002$ ), a relationship that has been observed at other sites (Cragg et al., 1990; 1992; Cragg, in press). Comparison with the numbers of dividing cells at the near-surface observed at other sites shows great similarity (Table 2), with $4.853 \times 10^{7}$ cells $/ \mathrm{cm}^{3}$ close to the average of $7.447 \times 10^{7}$ cells $/ \mathrm{cm}^{3}$. By approximately $80 \mathrm{mbsf}$ dividing cell numbers have reduced to $1.4 \%$ of the near-surface count and both this value and the absolute number of dividing cells at $80 \mathrm{mbsf}$ correspond with a descending sequence of sites based on oceanic productivity at each site (Table 2 ). Nevertheless, as with the total cell

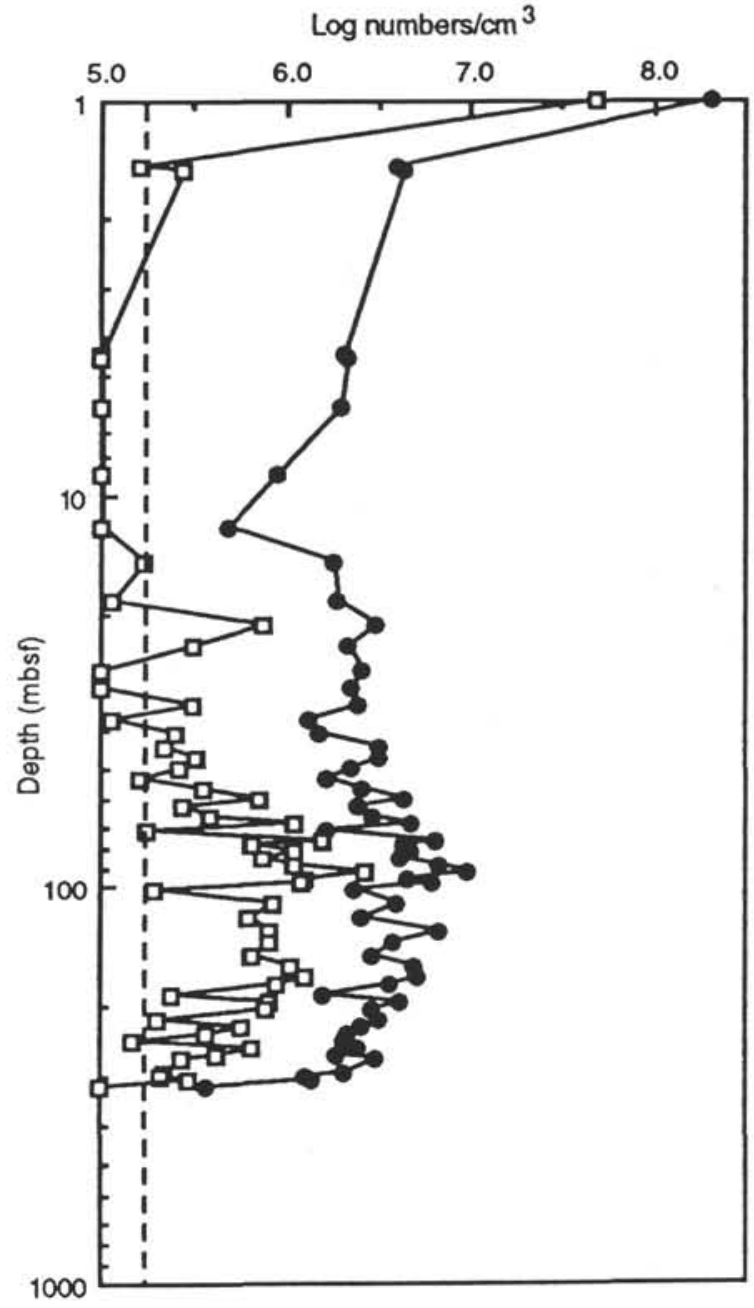

Figure 1. Depth distribution of total bacteria (dots) and dividing/divided cells (squares) to $317.4 \mathrm{mbsf}$ in Holes $851 \mathrm{~A}$ and $851 \mathrm{~B}$ (combined data). The dashed line at 5.2 is the calculated detection limit of $1.6 \times 10^{5} \mathrm{cells} / \mathrm{cm}^{3}$. (Depth values given on $\log _{10}$ scale to highlight near-surface data.)

count, this view is deceptive in that the numbers of dividing cells were actually increasing, by a factor of nearly 16 , over the depth range used for the comparison $\left(1.67 \times 10^{5}\right.$ at $15 \mathrm{mbsf}$ to $2.62 \times 10^{6}$ at $\left.91 \mathrm{mbsf}\right)$, concurrent with an increase in the organic carbon concentration between these depths (Fig. 2). Again, this emphasizes the importance of attempting to understand the past depositional environment to explain contemporary sediment bacterial distributions.

Numbers of dividing cells are significantly related $(R=0.610$; $N=34 ; P<0.002$ ) to the organic carbon concentration when calculated over the entire sediment column (Fig. 3). A similar relationship $(R=0.536 ; N=34 ; P<0.002)$ can also be demonstrated between the total count and organic carbon levels (data not shown), although the relationship is not as strong. This is not surprising as numbers of dividing cells may well represent a more sensitive index of bioavailable organic carbon than absolute numbers of bacteria in sediment layers where the bacterial populations and the organic carbon have been in intimate contact for perhaps many millions of years.

Geochemical data (Mayer, Pisias, Janecek, et al., 1992) suggest that any bacterial activity would be low at this site. Sodium, magnesium, calcium, and potassium profiles are invariant to the basement. This is attributed to the low organic carbon burial rate, resulting in fewer diagenetic effects, and an open-pore structure in the sediment, owing to the absence of a contiguous chert zone, which resulted in the dilution 


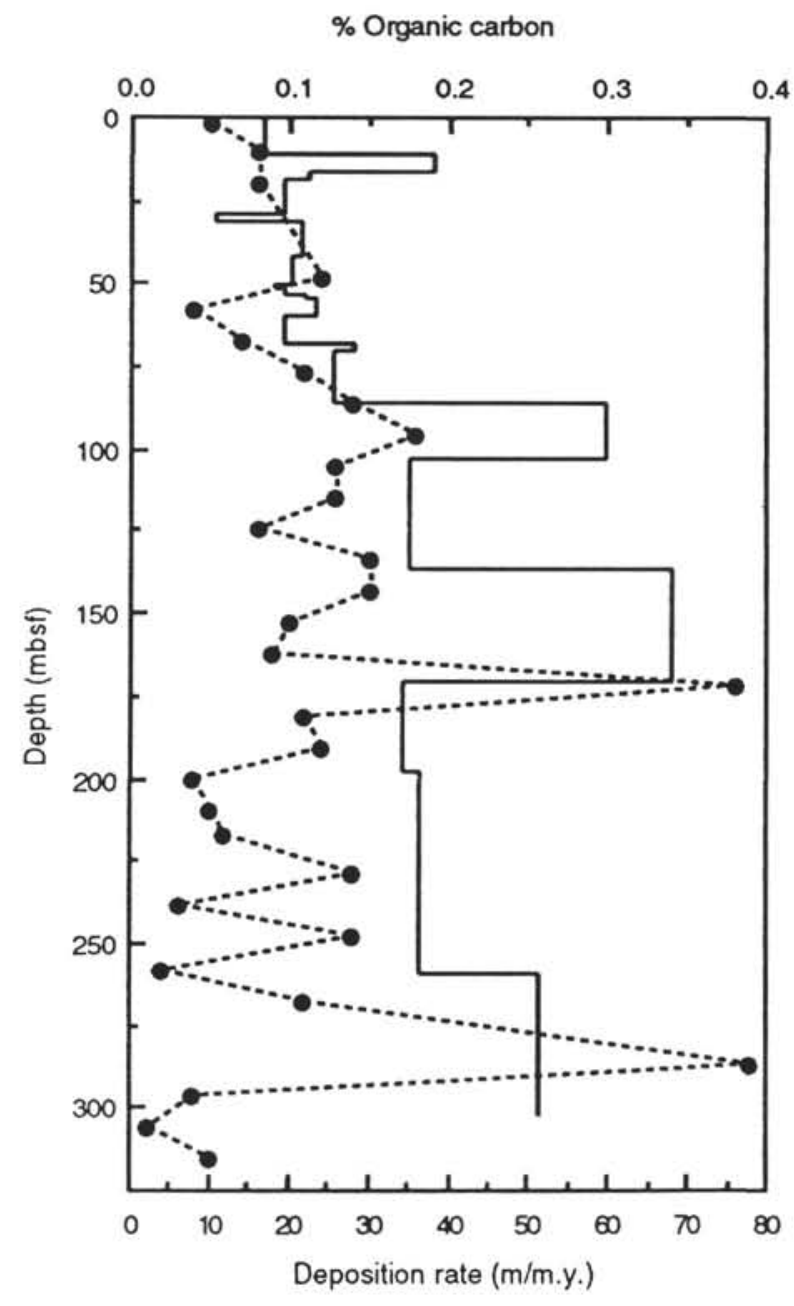

Figure 2. Depth distribution of percentage of organic carbon (dots) and sediment deposition rate (solid line) to $317.4 \mathrm{mbsf}$ at Site 851 . (Redrawn from Mayer, Pisias, Janecek, et al., 1992.)

of any localized changes in pore-water chemistry. In addition, no evidence of the vertical advection of pore waters can be seen.

Small, but detectable, changes were seen in concentrations of interstitial ammonia, alkalinity, and sulfate. Values of ammonia increased from $13 \mathrm{Mm}$ at $1.4 \mathrm{mbsf}$ to $101 \mathrm{Mm}$ at $165.8 \mathrm{mbsf}$ before declining to less than $10 \mathrm{mM}$ by $310.7 \mathrm{mbsf}$ (Fig. 4B). Alkalinity showed a similar profile, gradually increasing from $2.95 \mathrm{mM}$ at $1.4 \mathrm{mbsf}$ to a low maximum of $3.84 \mathrm{mM}$ at $165.8 \mathrm{mbsf}$ before declining to near-surface values at 310.7 mbsf (Fig. 4A). Conversely, concentrations of sulfate decreased from $27.31 \mathrm{mM}$ at $1.4 \mathrm{mbsf}$ to a minimum of $25.77 \mathrm{mM}$ at $195.8 \mathrm{mbsf}$ before rising to near-surface values at $310.7 \mathrm{mbsf}$ (Fig. 4C). However, the sulfate profile was not straightforward, as after an initial decline from 27.31 to $26.76 \mathrm{mM}$ between 1.4 and $5.9 \mathrm{mbsf}$, there was an increase to $28.11 \mathrm{mM}$ at $26 \mathrm{mbsf}$ (the highest concentration recorded) before the major decrease occurred. In addition, methane was present at low levels throughout the sediment core (Fig. 4D). After a relatively high value of $17.7 \mu \mathrm{L} / \mathrm{L}$ at $4.45 \mathrm{mbsf}$ it decreased abruptly to $1.3 \mu \mathrm{L} / \mathrm{L}$ at $13.45 \mathrm{mbsf}$. Below this depth, a trend of increase with local maxima $(>18 \mu \mathrm{L} / \mathrm{L})$ at $149.4,225.7$, and $292.9 \mathrm{mbsf}$ was seen before an abrupt decrease to zero at 310.6 mbsf (Mayer, Pisias, Janecek, et al., 1992). These geochemical profiles indicate a wide zone of slightly reducing pore water between about 30 and $290 \mathrm{mbsf}$. The variations in pore-water chemistry track changes in the profiles of total bacterial cells and dividing cell count with significant relationships observed between ammonia $(R=0.949 ; N=13 ; P<0.002$, and $R$

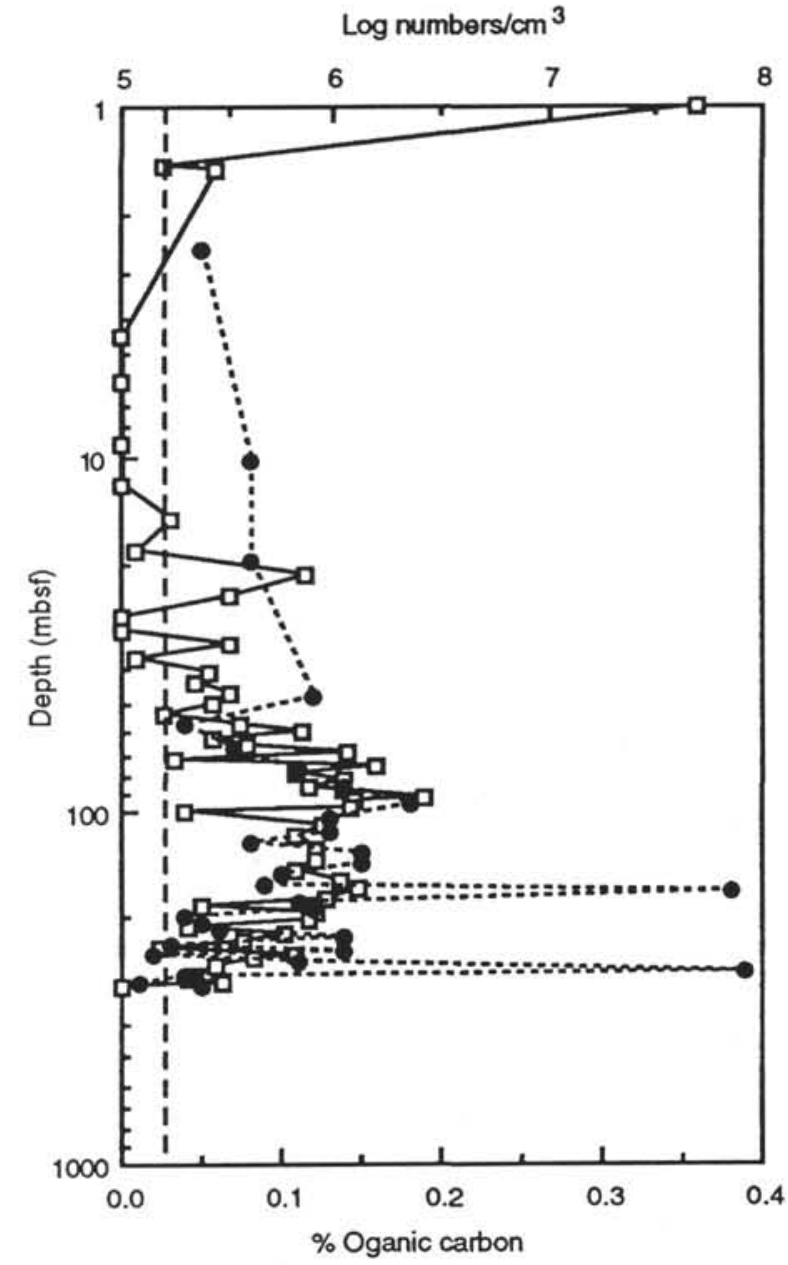

Figure 3. Depth distribution of numbers of dividing/divided bacterial cells (squares) and percentage of organic carbon (dots) to $317.4 \mathrm{mbsf}$ in Holes $851 \mathrm{~A}$ and $851 \mathrm{~B}$ (combined data). The dashed line at 5.2 is the calculated detection limit of $1.6 \times 10^{5} \mathrm{cells} / \mathrm{cm}^{3}$. (Organic carbon data from Mayer, Pisias, Janecek, et al., 1992; depth values given on $\log _{10}$ scale to highlight near-surface data.)

$=0.946 ; N=10 ; P<0.002)$, alkalinity $(R=0.791 ; N=15 ; P<0.002$, and $R=0.826 ; N=13 ; P=<0.002$ ), and, to a slightly lesser extent, sulfate concentrations $(R=-0.677 ; N=15 ; P<0.01$, and $R=-0.628$; $N=13 ; P<0.05$ ) for the total count and numbers of dividing cells, respectively. No such relationship was found between either cell count and methane concentration $(R=<0.2)$. This was expected, as methane gas in sediments will migrate upward and pore-water concentrations at any one depth will depend more on sediment porosity than in-situ bacterial count, particularly in sediments with low bacterial activity. Together with the observed relationship between both total count and numbers of dividing cells with organic carbon concentrations, these data indicate that a limited amount of bacterial activity (sulfate reduction and methanogenesis) is occurring within these sediments. Previous work (Cragg et al., 1990, 1992; Parkes et al., 1990) has produced good correlations between microbial parameters and geochemical data, and there is no reason to think that the implied relationship between the bacterial counts and changes in pore-water chemistry is not a realistic indicator of activity in the in-situ population.

The bacterial profiles between the near-surface and approximately $30 \mathrm{mbsf}$ are puzzling. Organic carbon concentrations are not particularly low (Fig. 2) and yet total counts decrease sharply and the numbers of dividing cells become not detectable by 1.48 mbsf and 


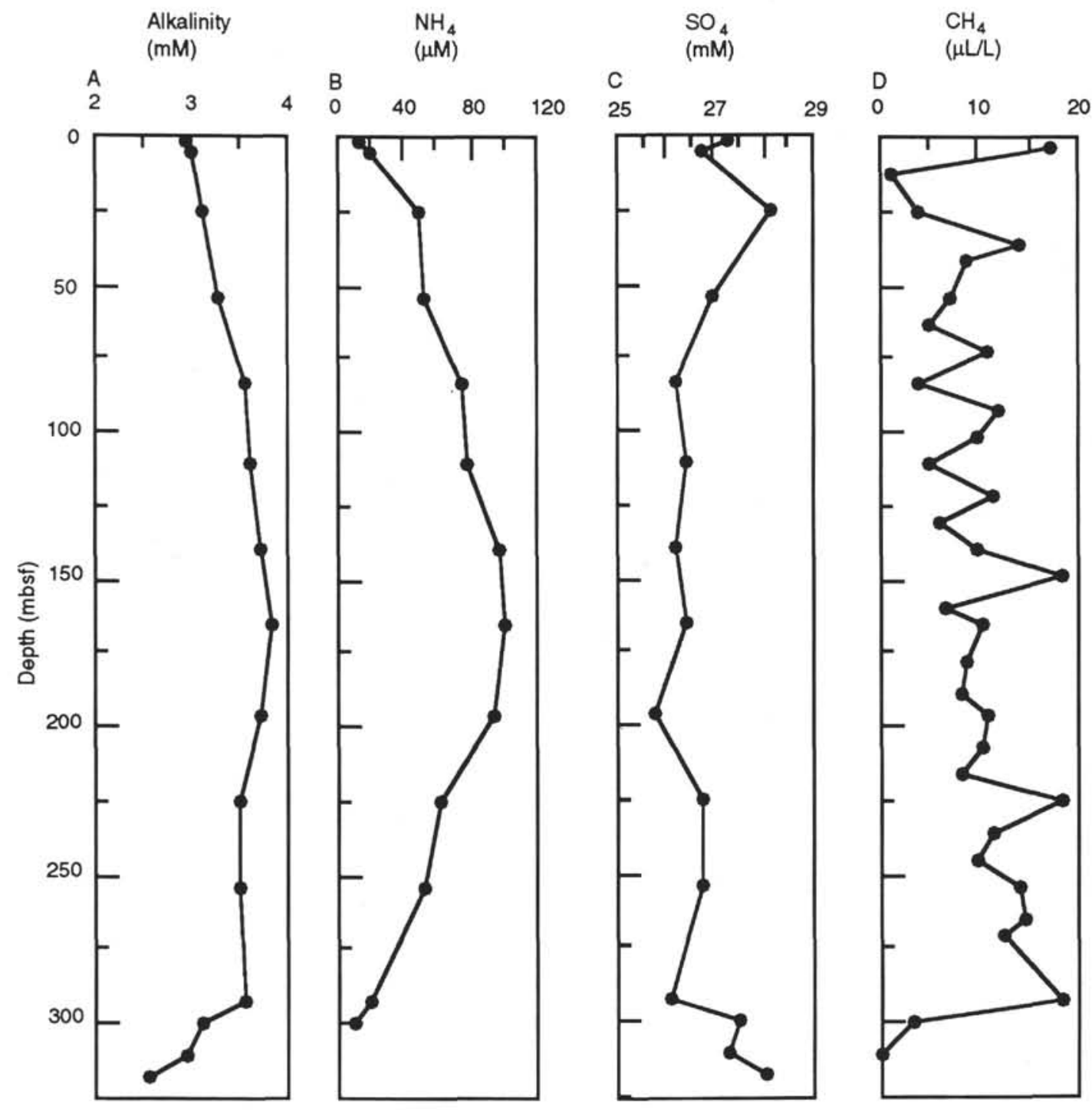

Figure 4. Depth profiles to $317.4 \mathrm{mbsf}$ in Holes $851 \mathrm{~A}$ and $851 \mathrm{~B}$ (combined data). A. Alkalinity. B. Ammonia. C. Sulfate. D. Methane. (Redrawn from Mayer, Pisias, Janecek, et al., 1992.)

remain low or absent (Fig. 1). Of the 11 occurrences of nondetectable dividing cells, seven such occurrences are within this zone. It is within this zone, however, that bacterial biomass is usually relatively high (Novitsky and Karl, 1986) and that activity rates are maximal (Fossing, 1990; Jørgensen et al., 1990). Over this same depth range, methane decreases from 17.5 to $1.3 \mu \mathrm{L} / \mathrm{L}$, alkalinity remains relatively constant (Fig. 4B), and sulfate concentrations increase (Fig. 4C), all of which is consistent with negligible bacterial activity. No changes were observed in either the organic or inorganic geochemistry of the porewaters (Mayer, Pisias, Janecek, et al., 1992), which would suggest reasons for the paucity of bacteria and bacterial activity within this zone; the lithostratigraphy recognizes no boundary at the 25- to $30-$ mbsf level. The only event recorded for this depth interval is the biostratigraphic definition of the Pliocene/Pleistocene boundary at approximately 26.5 mbsf (Mayer, Pisias, Janecek, et al., 1992). The middle Miocene to upper Pliocene sediments below this boundary appear to represent a band of elevated sedimentation rates encompassing most of the sediment column, which indicates a significantly different depositional history over much of the 11 m.y. represented by the sediment column compared to that over the last 1.6 m.y.

\section{SUMMARY}

Investigation of these Leg 138 sediment samples has shown low total and divided cell counts consistent with a low organic carbon environment. At the sediment near-surface, total counts, in comparison to similar counts from other ODP sites, suggest that the absolute numbers of bacteria on the sediment surface may be more strongly influenced by the depth of the overlying water rather than the annual primary productivity of that water column. The rate of decrease in bacterial numbers with depth, however, may be linked to the water column productivity. This interpretation is complicated by a rise in buried organic carbon between 30 and 290 mbsf which results in a significant increase in bacterial numbers with depth, unlike the depth profiles at other sites. The relationship between both total count and dividing cells with organic carbon indicate that a limited amount of bacterial activity is taking place in these sediments, and this is supported by the inorganic chemical data and methane levels which indirectly suggest that low levels of methanogenesis and sulfate reduction are occurring within this zone. Dividing cells were detected in all but two samples within the zone; however, both above $30 \mathrm{mbsf}$ 
and below $290 \mathrm{mbsf}$ a total of nine samples had no detectable dividing cells. At these depths, apart from the near-surface layers from 0 to 1.5 mbsf, geochemical analyses suggested bacterial activity was probably absent. Interpretation of the bacterial depth distributions at this site requires an understanding of the depositional history of the sediment, and this emphasizes the need to avoid making assumptions relating changes in sedimentary bacterial populations to depositional conditions at the current sediment surface.

\section{ACKNOWLEDGMENTS}

We thank R. John Parkes for constructive comments on this manuscript. This work was funded while B.A. Cragg was in receipt of a Special Topics Research Fellowship (GST/F90/2) provided by the Natural Environment Research Council, United Kingdom. We acknowledge the support and facilities provided by Bristol University, and we are grateful to the Ocean Drilling Program for supplying samples from Leg 138 and to John Miller who took some of the samples.

\section{REFERENCES *}

Balkwill, D.L., 1989. Numbers, diversity and morphological characteristics of aerobic chemoheterotrophic bacteria in deep subsurface sediments from a site in South Carolina. Geomicrobiol, J., 7:33-52.

Belyaev, S.S., and Ivanov, M.V., 1983. Bacterial methanogenesis in underground waters. In Hallberg, R. (Ed.), Environ. Geochem. Ecol. Bull., $35: 273-280$.

Berger, W.H., 1989. Global maps of ocean productivity. In Berger, W.H., Smetacek, V.S., and Wefer, G. (Eds.), Productivity of the Oceans: Present and Past: Rep. of the Dahlem Workshop, Berlin 1988: Chichester (Wiley), 429-455.

Bianchi, A., 1986. Heterotrophic bacterial types surviving in the Quaternary and upper Pliocene sediments of the Mahakam Delta. C. R. Acad. Sci. Ser. 3, 303:449-451.

Chapelle, F.H., and Lovley, D.R., 1990. Rates of microbial metabolism in deep coastal plain aquifers. Appl. Environ. Microbiol., 56:1865-1874.

Cragg, B.A., in press. Bacterial profiles in deep sediment layers from the Lau Basin, Site 834. In Hawkins, J., Parson, L., Allan, J., et al., Proc. ODP, Sci. Results, 135: College Station, TX (Ocean Drilling Program).

Cragg, B.A., Harvey, S.M., Fry, J.C., Herbert, R.A., and Parkes, R.J., 1992. Bacterial biomass and activity in the deep sediment layers of the Japan Sea, Hole 798B. In Pisciotto, K.A., Ingle, J.C., Jr., von Breymann, M.T., Barron, J., et al., Proc. ODP, Sci. Results., 127/128 (Pt. 1): College Station, TX (Ocean Drilling Program), 761-776.

Cragg, B.A., Parkes, R.J., Fry, J.C., Herbert, R.A., Wimpenny, J.W.T., and Getliff, J.M., 1990. Bacterial biomass and activity profiles within deep sediment layers. In Suess, E., von Huene, R., et al., Proc. ODP, Sci. Results, 112: College Station, TX (Ocean Drilling Program), 607-619.

Davis, J.B., 1967. Petroleum Microbiology: Amsterdam (Elsevier).

Erlich, H.L., and Ghiorse, W.C. (Eds.), 1989. Deep Subsurface Microbiology. Geomicrobiol. J., Spec. Iss. 7.

Fossing, H., 1990. Sulfate reduction in shelf sediments in the upwelling region off Central Peru. Cont. Shelf Res., 10:355-367.

Fredrickson, J.K., Balkwill, D.L., Zachara, J.M., Shu-Mei, W.L., Brockman, F.J., and Simmons, M.A., 1991. Physiological diversity and distributions of heterotrophic bacteria in deep Cretaceous sediments of the Atlantic coastal plain. Appl. Environ. Microbiol., 57:402-411.

Fry, J.C., 1988. Determination of biomass. In Austin, B. (Ed.), Methods in Aquatic Bacteriology: Chichester (Wiley), 27-72.

Getliff, J.M., Fry, J.C., Cragg, B.A., and Parkes, R.J., 1992. The potential for bacteria growth in deep sediment layers of the Japan Sea, Hole 798B - Leg 128. In Pisciotto, K.A., Ingle, J.C., Jr., von Breymann, M.T., Barron, J., et al., Proc. ODP, Sci. Results., 127/128 (Pt. 1): College Station, TX (Ocean Drilling Program), 755-760.
Goulder, R., 1977. Attached and free bacteria in an estuary with abundant suspended solids. J. Appl. Bacteriol., 43:399-405.

Ingle, J.C., Jr., Suyehiro, K., von Breymann, M.T., et al., 1990. Proc. ODP, Init. Repts., 128: College Station, TX (Ocean Drilling Program).

Jørgensen, B.B., 1983. Processes at the sediment/water interface. In Bolin, B., and Cook, R.B. (Eds.), The Major Biogeochemical Cycles and Their Interactions: Chichester (Wiley), 477-515.

Jørgensen, B.B., Bang, M., and Blackburn, T.H., 1990. Anaerobic mineralization in marine sediments from the Baltic Sea-North Sea transition. Mar. Ecol. Prog. Ser., 59:39-54.

Krumbein, W.E., 1983. Microbial Geochemistry: Oxford (Blackwell Sci.),

Lochte, K., and Turley, C.M., 1988. Bacteria and cyanobacteria associated with phytodetritus in the deep sea. Nature, 333:67-69.

Mayer, L., Pisias, N., Janecek, T., et al., 1992. Proc. ODP, Init. Repts., 138 (Pts. 1 and 2): College Station, TX (Ocean Drilling Program).

Novitsky, J.A., and Karl, D.M., 1986. Characterization of microbial activity in the surface layers of a coastal sub-tropical sediment. Mar. Ecol. Prog. Ser., 28:49-55.

Oremland, R.S., Culbertson, C., and Simoneit, B.R.T., 1982. Methanogenic activity in sediment from Leg 64, Gulf of California. In Curray, J.R., Moore, D.G., et al., Init. Repts. DSDP, 64 (Pt. 2): Washington (U.S. Govt. Printing Office), 759-762.

Parkes, R.J., Cragg, B.A., Fry, J.C., Herbert, R.A., and Wimpenny, J.W.T., 1990. Bacterial biomass and activity in deep sediment layers from the Peru margin. Philos. Trans. R. Soc. London A, 331:139-153.

Parson, L., Hawkins, J., Allan, J., et al., 1992. Proc. ODP, Init. Repts., 135: College Station, TX (Ocean Drilling Program).

Phelps, T.J., Fliermans, C.B., Garland, T.R., Pfiffner, S.M., and White, D.C., 1989. Methods for recovery of deep terrestrial subsurface sediments for microbiological studies. J. Microbiol. Methods, 9:267-279.

Rittenberg, S.C., 1940. Bacteriological analysis of some long cores of marine sediments. J. Mar. Res., 3:191-201.

Sørensen, J., 1978. Denitrification rates in marine sediment as measured by the acetylene inhibition technique. Appl. Environ. Microbiol., 36:139-143.

Sørensen, J., and Jørgensen, B.B., 1987. Early diagenesis in sediments from Danish coastal waters: microbial activity and $\mathrm{Mn}-\mathrm{Fe}-\mathrm{S}$ geochemistry. Geochim. Cosmochim. Acta, 51:1583-1590.

Suess, E., von Huene, R., et al., 1988. Proc. ODP, Init. Repts., 112: College Station, TX (Ocean Drilling Program).

Tarafa, M.E., Whelan, J.K., Oremland, R.S., and Smith, R.L., 1987. Evidence of microbiological activity in Leg 95 (New Jersey Transect) sediments. In Poag, C.W., Watts, A.B., et al., Init. Repts. DSDP, 95: Washington (U.S. Govt. Printing Office), 635-640.

Turley, C.M., and Lochte, K., 1990. Microbial response to the input of fresh detritus to the deep-sea bed. Palaeogeogr., Palaeoclimatol., Palaeoecol., 89:3-23.

Whelan, J.K., Oremland, R., Tarafa, M., Smith, R., Howarth, R., and Lee, C., 1986. Evidence for sulfate-reducing and methane producing microorganisms in sediments from Sites 618,619, and 622. In Bouma, A.H., Coleman, J.M., Meyer, A.W., et al., Init. Repts. DSDP, 96: Washington (U.S. Govt. Printing Office), 767-775.

White, D.C., Fredrickson, H.F., Gehron, M.H., Smith, G.A., and Martz, R.F., 1983. The groundwater aquifer microbiota: biomass, community structure and nutritional status. Dev. Ind. Microbiol., 24:189-199.

ZoBell, C.E., 1958. Ecology of sulfate reducing bacteria. Prod. Mon., 22:12-29.

\footnotetext{
"Abbreviations for names of organizations and publication titles in ODP reference lists follow the style given in Chemical Abstracts Service Source Index (published by American Chemical Society).
}

\footnotetext{
Date of initial receipt: 5 January 1993

Date of acceptance: 15 November 1993

Ms 138SR-130
} 